\title{
Canary Science in the Mineshaft of the Anthropocene
}

\author{
Liza Grandia
}

ABSTRACT: Alongside the melting of glaciers, human bodies warn of another petrochemically driven planetary crisis. Much as climate science ignored the early warning observations of Indigenous peoples, the medical establishment has often dismissed the canaries struggling to survive in the mineshaft of modernity. In an aleatory Anthropocene, we know not for whom the toxicity will toll. While case studies of environmental justice remain essential, the privileged must also be jolted into understanding their own ontological precariousness (i.e., vulnerability) from toxicants pervasive in everyday life. Moving beyond "citizen science" with inspiration from feminist ethics of care and relational Indigenous epistemologies, I make a case for the extrasensory value of "canary science." If managerial "risk" was the keyword of the profiteering twentieth century, a sense of shared vulnerability in the coronavirus era could help usher in the transitions needed for survival in this polluted world.

KEYWORDS: canaries, COVID-19, environmental justice, MCS, risk, vulnerability

"It's the end of the world as we know it, and I [don't] feel fine."

$-\mathrm{REM}$

"First to fall over when the atmosphere is less than perfect, Your sensibilities are shaken by the slightest defect.

You live your life like a canary in a coal mine."

-The Police

When CNN anchor Chris Cuomo spoke candidly about his exhaustion, "brain fog," and other prolonged COVID-19 symptoms on prime-time news on 13 April 2020, the social media groups for the chemically injured went aflutter. Having themselves been medically gaslighted as anxious, hysterical, or clinically depressed for similar dysautonomic symptoms of aphasia and short-term memory loss, these communities of chemically sensitive folk, who perceive themselves as canaries, sang vindication. Cuomo epitomizes privilege-wealthy, White, fit and able-bodied, cisgender, political family heir, male, handsome, Ivy-educated, medically insured, and brother to then New York's governor. Nevertheless, like me, COVID conscripted him into the early ranks of the "long-haulers" with our mysterious maladies and existential uncertainties.

Should I have revealed my cards so early in this article? The devil of my twentieth-century critic whispers to bluff and conceal my subjectivity. Reviewers could dismiss you as a "popularizer" and suggest that you turn the article into a blog post. The angel watching over my broken 2020 self, however, animates me into reflexive disclosure: I am thrice a "canary in the 
coal mine"-having survived lymphoma in my thirties, coped with severe multiple chemical sensitivity (MCS) in my forties, and now converted into a COVID "long-hauler" on the cusp of my fifties. Rest assured: this shall not be a pity party. Prior to becoming chronically ill, I lived many fulfilling years in Q'eqchi' Maya communities and fully recognize that as a tenured cultural anthropologist with US citizenship I also embody other sets of geopolitical and intellectual privilege. My vulnerabilities, however, present a point of departure to one of this volume's queries: how to theorize toxicity into political mobilization.

Alongside the melting of glaciers, human bodies like mine warn of another planetary crisis. Hundreds, if not thousands, of pollutants have trespassed into the blood of humanity (CDC 2009; Baker 2008). Although the environmental justice literature has documented and denounced the uneven impacts of pollution, the mainstream media by and large still ignores racialized patterns of chemical assault. As a new angle into these debates, I draw comparative attention to ubiquitous lethal pollutants encountered by even the most privileged in everyday life. Elsewhere, I have discussed the unpredictability of chemical injury through philosopher John Rawls's (1971) deductive "veil of ignorance" (Grandia 2019). As ecologist Sandra Steingraber (1997) emphasizes, we are all "downstream" from something. She therefore concludes: "We don't know who the victims are, but we know that when you release certain chemicals into the environment, a certain number of people are going to get cancer and die because of that" (1998: 7). In an aleatory Anthropocene, we know not for whom the toxicity will toll.

As it stands, one in two men and one in three women will get cancer in their lifetimes. In the United States, pediatric cancer has risen by 50 percent over the last three decades and is the second leading cause of death for children under the age of 15 (Landrigan and Landrigan 2018). Rates of my own cancer, lymphoma, have tripled since 1950, doubling in just the last two decades. Worldwide, the number of new cancer diagnoses is expected to increase by 45 percent between 2008 and 2030 (WHO and International Union against Cancer 2005). With an estimated 9.5 million deaths as of 2018, cancer kills almost four times the number of people who die annually from malaria (409,000), tuberculosis (1.5 million), and AIDS (690,000) combined. Two-thirds of new cases will be in impoverished countries, where mortality rates are twice those of rich countries (WHO 2021). Among men in North America, Europe, New Zealand, and Australia, sperm counts have declined 59 percent between 1973 and 2011 (Levine et al. 2017). Asthma rates more than doubled in the United States between 1980 and 1995 (Redd 2002). Writ large, one in two Americans suffer from a chronic illness (with many comorbidities) with disproportionate burdens among communities of color.

Why have these alarming statistics not triggered our institutions into similarly geometric research budgets to track causes for this sudden rise in environmentally related illnesses?

The chemical culprits are anyone's guess. At the moment, US laws consider chemicals safe until enough bodies pile up to prove them guilty. This is, in part, because the United States Congress classified the estimated 62,000 chemicals already in commerce as safe without any further research in order to avoid industry opposition to the 1976 Toxic Substances Control Act (TSCA). Since then, the Environmental Protection Agency (EPA) has only managed to collect systematic data on 200 or so chemicals and to assemble sufficient weight of evidence to ban just five (Baker 2008). The EPA typically uses one in a million as the de minimis risk level for acceptable exposure to suspected mutagens. Having been that one, I and other cancer survivors may beg to differ about tolerable risk.

Much as climate science ignored the early warning observations of Indigenous peoples, the medical establishment has dismissed the canaries struggling to survive in the coal mine of this toxic modernity. If humanity is to solve its chemical problem before the damage becomes irreparable, those who have already fallen environmentally ill at doses considered "safe" have 
much to teach us all epidemiologically and epistemologically. Against a medical establishment that often gaslights those afflicted with environmental illness, I began my literature review as an impatient patient searching for my own clues to causality and healing. Along this journey, other vulnerable "book-collar" workers provided interpretive balm through their own embodied analyses. ${ }^{1}$ Moving beyond "citizen science," with inspiration from feminist ethics of care and relational Indigenous epistemologies, in this article I make a strategic case for the extrasensory value of "canary science" to inspire a political shift from "risk" discourse to stronger regulatory programs to address the mutual vulnerability of all peoples to pollutants.

\section{From Risk to Vulnerability}

With the neoliberal erosion of Keynesian programs and the rollback of minuscule environmental regulations, precarity has become a new transdisciplinary academic concept for rethinking the risk and instability of the post-welfare state (Han 2018). Much of this scholarship has followed Guy Standing's (2014) provocative idea of the "precariat" as a new, disruptive economic class unified not by occupation or income, but by how quickly things might fall apart (Han 2018). In embracing the terminology of the "precariat," millennials and others remind us that most of us are just a few paychecks (if not a single paycheck) away from financial disaster. As planetary crises mount, apocalypticism and millennialism have shifted from fringe movements (Stewart and Harding 1999) to a generalized cultural condition. Moving into a future without the promises of stability, teleology, predictability, or security of Fordist capitalism (Weston 2012), the concept of precarity might propel us into the "condition of being vulnerable to others" (Tsing 2015: 20) and inspire a new "biopolitics from below" for collective organizing (Allison 2014). In fact, through a double movement (Polanyi 1944) of general assembly, urban farming, and new modes of living on a damaged planet, millennials are teaching us new ways of "navigating uncertainty in search of the good life" (Hardon 2021) without the traditional arc of middle-class comfort and accumulation into retirement.

At the same time, inherited neoliberal tendencies to self-help, self-surveil, and parse risk remain pervasive. While White male theorists (Beck, Giddens, Harvey, etc.) heretofore dominated the grand discourse on risk and neoliberalism, emerging work by Indigenous, feminist, and anthropological theorists remind us that "there might not be a collective happy ending" (Tsing 2015). Building on Arendtian politics and subaltern studies, Judith Butler began to explore precarity as an umbrella category that might unify the intersectional quandaries of "women, queers, transgender people, the poor, and the stateless" (2009: xiii). In this germinal work, Butler distinguishes between precarity (the differential distribution of the risk of early death as a consequence of socioeconomic and racial categorizations) and precariousness (the ontological recognition of our mutual mortality, or, as Martin Heidegger put it, "being-towarddeath") (Kasmir 2018). Because my own chemically damaged memory finds it hard to recall these nuances, and because environmental anthropology hardly needs another neologism, I would pose an easier mnemonic contraposition of precarity and vulnerability, as illustrated in Figure 1.

Largely focused on precarity, the environmental justice (EJ) literature investigates toxic sedimentation and residues in particular places (Boudia et al. 2018) to critique the differential distribution of environmental risk in society. Despite eloquent academic denunciations, however, reckoning and restitution for those with disproportionate toxic burdens remains elusive in part because the sites of so many EJ struggles are geographically out-of-sight and therefore out-ofmind for cosmopolitan elites. Without diminishing the imperative for continued high-quality 
Figure 1. Duality of vulnerability and precarity (Source: Liza Grandia).

\begin{tabular}{|l|l|}
\hline Vulnerability (“precariousness" in Butler) & Precarity \\
\hline Universality of death that awaits us all & Uneven distribution of entitlements for recovery \\
\hline $\begin{array}{l}\text { Radical relationality; ecological interconnections } \\
\text { and flows }\end{array}$ & Sedimentation, residues \\
\hline $\begin{array}{l}\text { Intrinsic or lifecycle susceptibilities (e.g., } \\
\text { developmental risks to babies) }\end{array}$ & $\begin{array}{l}\text { Differential distribution of extrinsic stressors by } \\
\text { class, race, and other social categories }\end{array}$ \\
\hline $\begin{array}{l}\text { "Canary science," as warning to the populace at } \\
\text { large }\end{array}$ & $\begin{array}{l}\text { Environmental justice, reckoning, and restitution } \\
\text { for "canaries" }\end{array}$ \\
\hline
\end{tabular}

scholarship on environmental injustices, my suggestion here is for a companion theory of anticipatory vulnerability to elicit expanded curiosity, compassion, and concern in circles of power about their own personal risks in order to secure tighter environmental regulation that would protect everyone from chemical harm. Somehow, we need to strike personal panic into the privileged about how toxicants move through the commodity chain into their own bodies to compel them to develop comprehensive solutions rather than partial, palliative fixes doled out to the few heroic communities that effectively mobilize against environmental racism.

Black, Brown, and Indigenous communities are undeniably dying young from imbricated environmental crises, economic crashes, infectious pandemics, police brutality, and more. As Martin Niemöller began his much-cited speech about complicit apathy to the Nazi purges: "We knew it, it was printed in the newspapers." Here is my own toxic riff to an edited poem composed from his speech at the US Holocaust Memorial Museum:

First the toxics came for people of color, but I did not raise my voice, because I was not of color. Then even White women fell ill with rising rates of breast cancer, and I did not speak out-because I was not afflicted. Then the children could not breathe and could not concentrate, and I did not speak out-because I am grown. Then, people became allergic to modern life, and, although millions went missing, I did not speak out because they were too homebound and fatigued to be noticed. Infertility was on the rise, but I did not speak out because I could blame this on women. Then, the endocrine disruptors clearly came for my sperm, but there was no one left to speak out for me.

How, then, to broaden the early alarm signs from EJ or canary communities to the broader society? To encourage the White, wealthy men in grey suits who, for the moment, still run the world to recognize toxic (or infectious) threats before it is too late represents a decided shift in ethnographic voice away from "difference" and toward an emphasis on the power of alliances, solidarity, and transnational social movements. For certain, in my community talks to Kiwanis clubs about toxics in everyday life audiences perk up whenever I talk about sperm counts or diminished male birth rates. ${ }^{2}$ As Clara Han notes, everyday stories at the "scale of the human body" (2018: 340) are needed to mobilize the full conceptual power of precarity from its critique of late capitalism into how we might collectively come together to face the "syndemics" (Singer and Clair 2003) of the twenty-first century. Obviously, divergent interests and ideologies drive the ecologies of the poor and the privileged (Guha and Martinez-Alier 1997), so care must be taken to avoid false unity or erroneous equivalences of an intoxicated "we" (Chen 2011). Nonetheless, the scale, scope, and consequences of this Anthropocenic pollution crisis compel us to build bigger tents and alliances about pollution risks-and to do so with some cultural and cognitive savvy. 
Faced with the sheer mathematical difficulty of fathoming parts per billion or joules per kilo (Starr 1969), people fall back upon other social criteria to rank and prioritize environmental problems to be solved (Douglas and Wildavsky 1983). As the Niemöller poem so aptly demonstrates, perceptions of risk are an iterative process-meaning prior perception of risk shapes subsequent behavior and therefore alters later encounters with risk (Kellow 1999). Shaped by emotions, values, politico-social complexities, and subjectivities, risk interpretation is deeply cultural (Douglas and Wildavsky 1983). Cognitive psychological studies show that EuroAmerican subjects tend to normalize and underestimate routine exposures (whether by residence, occupation, or habit) and overestimate the probability of catastrophic events (e.g., nuclear fallout). When disasters overlap or become chronic (Couch and Kroll-Smith 1985), even cautious people may become more cavalier about everyday risks. Worse yet, as evidenced by the wild stock market fluctuations of 2020, the lords of corporate capitalism grotesquely speculate on risk as a business opportunity, whereas millennial Indigenous cultures more wisely recognize their common precarity to external threats. Indeed, race and gender appear to inflect risk perception far more than income or education. White men rank risks lower than any other group (Flynn et al. 1994) - a pattern newly apparent in the bizarre US war over protective masking and vaccines against COVID-19 infection that has prolonged the pandemic.

Yet, even those with centuries of accumulated perks and privileges stand vulnerable to planetary pollution and pandemics. Just as COVID came for Hollywood stars, athletes, politicians, and other high-profile public figures, the cancer reaper routinely appears for a surprising number of White, male, billionaire CEOs (e.g., Steve Jobs, Sam Walton, Paul Allen, and David Koch). When toxicological (or infectious) harm comes from even low dose exposure, no one benefits from toxicity. That said, the 99 percent clearly do not share the same entitlements for recovery from adversity as the 1 percent elites can muster when facing life's personal tragedies.

Let me reiterate this fundamental point again, lest I be misunderstood. Cancer and other environmental health problems indisputably affect people of color, the poor, and Indigenous groups at reprehensibly higher rates. Especially for Indigenous peoples who cannot or do not want to relocate from their sovereign territories, their emplaced suffering is clearly not commensurable with that of more mobile classes who have lost their relationality with the land. As of 2014, one-quarter of the nation's 1,322 Superfund sites are on Native American reservations, with measurable consequences for Native health. While the US cancer rate generally rose four percent between 1973 and 1990, it increased by 10 percent among Native Americans in the same period (Baker 1997); Yupik have 4-12 times higher PCB levels than the general US population (Hoover et al. 2012); in Oceti Sakowin territory (Northern Plains region), cancer mortality is 40 percent higher than the general population (Hoover et al. 2012); and two-fifths (40 percent) of the Amijwnaang (Ojibwe) community rely on asthma inhalers to breathe the air of their sacred homelands, which are now surrounded by Canada's "Chemical Valley" in Southeastern Ontario, just across the border from Port Huron, Michigan (Hoover et al. 2012).

The latter story merits further detail. Canada is the fourth-largest oil producer in the world, and 40 percent of its petrochemical industry is located within 15 miles of the Sarnia Valley. Permitted emissions levels are 50 times greater than the United States's own infamous Cancer Alley in Louisiana. Nearly a thousand Chippewa/Anishinaabe tribal members live on a small reserve smashed in between Dow, Shell, and Suncor refining plants (the latter of which is located on their burial grounds) (Aamjiwnaang First Nation n.d.). Once an abundant territory supporting some 15,000 people, today their food, medicine, water, air, and ceremonial materials are so contaminated by endocrine-disrupting petrochemicals that the male/female birthrate is notably skewed 35/65 percent, and two out of five women have suffered a miscarriage or stillbirth (Toledano 2013). Worse yet, the rocks are so coated with oil residue that the community can no 
longer continue their healing sweat lodges to detoxify the social and physical body (Bienkowski 2002) from the intergenerational environmental violence of corporate capitalism (Murphy 2020).

As Michelle Murphy emphasizes with her concept of "chemical regimes of living" (Murphy 2008), toxicants circulate and seep into bodies far beyond point sources in the atmosphere, soils, water, and consumer products. The plastic fabricated in the Sarnia Valley releases bisphenol A (BPA) into wild and human bodies. Although there are no safe levels of exposure for pregnant women, the Centers for Disease Control and Prevention (CDC) found this chemical in 92 percent of women of reproductive age and children (EPA 2013). In later reflections of how to connect new imagined communities (Anderson 1983) around those extended toxic commodity chains, Reena Shadaan and Michelle Murphy reject neoliberal environmental solutions like labels, consumer education, or new housecleaning demands (whose labor falls disproportionately on women), toward broader decolonial and feminist demands for regulation that would "shift our gaze beyond individualist framings and solutions and towards structures of power, oppression, and exploitation" (2020: 24).

While condemning the pollution of factory towns that DuPont poisoned with polyfluoroalkylated substances (PFOAs) that never decompose, one must wonder what the manufactured Teflon and stain repellants in 99 percent of our blood samples are doing to all of us. While denouncing the horrific conditions of China's "cancer villages" (Lora-Wainwright 2010), one must question what "wish.com" bargains bring into middle-class homes. While recognizing the evidently high rates of cancer among Mexican immigrant carpet factory workers and installers, one must nevertheless raise questions about the glues and coatings on wall-to-wall carpets in daycare centers and schools (Changing Markets Foundation 2018; Grandia 2020). According to Mary Douglas, "we shall not expect to understand other people's ideas of contagion, sacred or secular, until we have confronted our own" (1966: 29).

So long as wealthy suburbanites remain unconcerned about formaldehyde in Johnson \& Johnson baby shampoo, they are unlikely to care about shocking formaldehyde levels in FEMA trailers recalled and re-"gifted" to Native American reservations after they made Hurricane Katrina evacuees ill (Shapiro 2014). Continuing the toxic tally of this one American corporation, so long as baby boomers remain apathetic about having powdered my generation's bums in a plume of asbestos from Johnson \& Johnson talc, few may care that Native Americans are disproportionately at risk for mesothelioma and other asbestos-related diseases. As long as teens willingly buy Neutrogena coal tar shampoo (despite being on California's Prop 65 list of carcinogens) to treat adolescent dandruff, the next generation of political leaders are unlikely to allocate funding to remediate the toxic sludge from open-pit coal mines on Native lands. As long as mothers continue buying Johnson \& Johnson's "baby cologne" containing endocrine-disrupting chemicals hidden under the label of "fragrance," they are unlikely to care about the aforementioned reproductive hazards to the Aamjiwnaang (Anishinaabe/Ojibwe) Nation living in Sarnia Valley (Hoover et al. 2012).

One silver lining of sudden, concurrent, or sequential technological and other disasters such as the relentless crises of 2020 is that the privileged have been temporarily shocked into recognizing their vulnerability and the need for broad epidemiological studies for collective public health solutions. To take another Johnson \& Johnson example, proper correlation of blood clots with the COVID-19 vaccine would need to rule out thrombosis associated with organophosphate pesticides-a correlation that the physician William Rea (1992-1997) observed in himself and his patients with multiple chemical sensitivity. Crises like COVID-19 create contexts in which everyday power relations and arrangements may be more clearly perceived, confronted, and converted into citizen action (Oliver-Smith 1996). As occurred in the aftermath 
of the nuclear meltdowns in Fukushima and Chernobyl, the Bhopal disaster, dioxin release in Seveso, Italy, or numerous oil spills, mass victims of involuntary technological accidents, especially those involving invisible hazards like radiation, tend to lose faith in the authority of the state, corporate power, and even science itself (Beamish 2001; Brown 2001). Amid crises, subaltern voices with more cautionary perceptions of risk to the White patriarchy can be suddenly heard. Into this fray of uncertainty, courageous communities have begun asserting their own perspectives on risks of environmental modernity and demonstrating their capacity to analyze pollution through new eyes, metrics, and science in the flesh.

\section{Citizen Science into Canary Science}

Coined in the mid-1990s by Rick Bonney, the term "citizen science" formally entered the Oxford English lexicon in 2014. Between 1997 and 2014, the number of academic publications crediting citizen participation has risen 250 -fold. Working at a scale and scope previously not affordable or in locations off the grid (Stevens et al. 2014), low-cost computer technology has allowed students, weekend naturalists, computer programmers, and other types of tinkerers to participate in scientific research. Citizen science clearly spans a spectrum from "extreme" participation whereby participants help define the problem, to "moderate" distribution of power whereby participants contribute to analysis, and finally onto potentially "exploitative" projects whereby citizens merely serve as crowdsourced labor for corporate benefit (Haklay 2018). Although collaborative lay science could have disruptive potential, most of what constitutes "citizen science" today appears to be a voluntary, neoliberal extension of the lab to amateurs who help gather, transcribe, or analyze data in service of professional scientists. Seasoned international development scholars skeptical of claims to "participatory" processes may recognize here a type of Fergusonian "anti-politics" machine (Ferguson 1994). Like androcentric Western experimental science based on (White) adult males (Pezzullo 2014), citizen science disproportionately attracts middle-class, White male participants (West et al. 2016). It can also perpetuate a pattern noted by anthropologists of one-way directionality "where information flows from scientists to passive recipients" rather than examining how "science is embedded in power relations and subjective interests" (Checker 2007: 116).

To sustain the field's legitimacy, its founders and core proponents retain technocratic and paternalistic concerns about data quality and rigor (Bonney et al. 2014). Rather than prioritizing science that is responsive to citizen concerns, the field has been lately preoccupied with legitimizing the reliability of citizen science. As cofounder Bonney lamented to a journalist, "some [projects] are high quality and some are slipshod, and it's hard for people to tell the difference. That's one reason we started the Citizen Science Association, to bring more quality control to the field. One thing I'd support is voluntary certification of citizen science projects-a stamp of approval" (Baker 2016: 927).

As anthropological critics have long contended, true democratization of science must eschew positivism; shift scientific paradigms (Feyerabend 1978); decentralize control (Nader 1995); recognize its own cultural biases (Gusterson 1996); acknowledge the scientific illiteracy among the general population of even the most advanced industrialized societies (Worsely 1997); confess its cultural appropriation of other scientific traditions without acknowledgment (Nadasdy 1999); and recognize the potential etiological wisdom of older medical traditions than the West's (Nader 1996). Much as his older brother's (Karl's) work on political economy presciently valued Indigenous reciprocity and culturally embedded economy, Michael Polanyi drew attention to the prevalence of "tacit knowledge" within Western scientific systems. If we could strip capital- 
ized Science to its naked core as a system for observation and understanding of our world, then we would have to ecumenically recognize the plurality of science (Nader 1996) and the value of traditional ecological knowledge (Gilio-Whitaker 2019).

The environmental justice literature abounds with stories of how its subjects followed their intuition, swapped stories over kitchen tables, and began organizing to map and survey community exposure. Their "popular epidemiology" (Brown 1992), "naked science" (Nader 1996), "street science" (Corburn 2005), and movements for "environmental reproductive justice" (Hoover et al. 2012) brought new questions, hypotheses, and even monitoring technologies (cf. Gwen Ottinger's [2010] exemplary, engaged scholarship with the "bucket brigades" that have transformed air quality monitoring paradigms). Belittled by doctors and subverted by the biases of risk assessment, as Melissa Checker's (2007) poignant title emphasizes, environmentally contaminated communities insist: "But I know it's true." When not suppressed by entrenched powers and when experts are willing to listen, their firsthand, observational data can offer new insights into environmental illness (Ottinger and Cohen 2011). These types of "small sciences" (Nader 1996) are "less ensnared in bureaucratic turf" or subject to corporate pressure; they are also explicitly and "avowedly political" (Nading 2020: 217).

While I primarily write here about the first entendre of canary as a sentinel in the coal mine (cf. Buell 1998; and Nading 2020), its secondary meaning of whistleblowers or informants that "sing like a canary" to the authorities is also applicable. ${ }^{3}$ Defectors like former chemical corporation lawyer Rob Bilott (2019) harnessed insider knowledge that helped him uncover one of humanity's worst mass poisonings. What began as a quintessential EJ case (investigating the sentinel deaths of cows on a farm near the DuPont factory and a cancer cluster in the adjacent town of Parkersburg, West Virginia) blossomed into the largest epidemiological study in human history (the C8 Health Project funded by DuPont in its settlement agreement with Jack W. Leach, et al.). Not only were the canary workers poisoned, but the whole of America (and likely the world) now has a class of nondegradable compounds, PFOAs (therefore dubbed as "forever chemicals"), coursing in their blood.

To give one final example, despite being the worst radioactive spill in US history, the 1979 Church Rock accident on Navajo lands received minimal press coverage: "But there's irony there: because so little public attention focused on the United Nuclear Company's Churchrock's 'booboo, no one bothered to follow the flow of water from the Rio Puerco into the Little Colorado River, the Colorado River, and finally Lake Mead-which is a source of water for the mostly white, urban population living west of Las Vegas" (LaDuke 1982: 3). Elizabeth Hoover's (2017) inspirational work with Mohawk scholar-midwife Katsi Cook shows how collaborative partnerships with communities produce better environmental science. Another exemplary figure is Pamela Miller, who has leveraged her engaged research with the Alaska Community Action on Toxics on POPs (persistent organic pollutants) and other chemicals that bioaccumulate in the Arctic to ban them at a global level through the Stockholm Convention (Miller et al. 2013). We need more such bricolage work that follows the watershed and other long pathways of toxicity. Without broader political consciousness about the military-industrial-genocidal complex, no amount of "participatory" or "citizen" science will remediate the nuclear and other high environmental crimes committed against Native nations.

Following Felix Cohen's work, Vine Deloria, Jr., David Wilkins, and other Native legal scholars have argued that "the degree of justice enjoyed by indigenous peoples ... was the equivalent of a miner's canary in the realm of human rights because what happens to Indians in their political vulnerability can easily happen to the 'rest of us'" (Biolsi 2002: 242). Others have utilized the miner's canary metaphor to critique extractivism and genocide (Andersen 2010; Weaver 2010), 
while Native legal scholar Gerald Torres with his coauthor Lani Guinier in an eponymous book maintain that racism injures everyone:

\begin{abstract}
Even though the canary is in a cage, it continues to have agency and voice. If the miners were watching the canary, they would not wait for it to fall off its perch, legs up. They would notice that it is talking to them. "I can't breathe, but you know what? You are being poisoned too. If you save me, you will save yourself. Why is that mine owner sending all of us down here to be poisoned anyway?" (Torres and Guinier 2002: 259)
\end{abstract}

As Native American political prisoner Leonard Peltier more succinctly put it: "The injustice you allow against others will become the injustice that comes against you."

\title{
Canaries
}

From the iconic story of bald eaglets dying from DDT (dichlorodiphenyltrichloroethane), birds have proven their charismatic mettle as sentinel creatures (Carson 1962). With North Americans spending 90 percent of their lives indoors, it seems apropos that a domesticated species (Serinus canaria forma domestica) would emerge as a symbol for everyday exposure to toxicants, especially with regard to indoor air quality. To give a brief history of their domestication, in the seventeenth century Spanish sailors brought the songbirds back from a mid-Atlantic archipelago known as Macaronesia (including the eponymous "Canary Islands"). Initially bred exclusively by monks, only the singing males were sold as parlor pets to royal courts and other elites, but eventually they spread among European common folk.

Prior to canaries, miners used mice, guinea pigs, rabbits, and other less sensitive sentinel species to detect carbon monoxide, a fatal but odorless gas. In the 1880s, a Scottish physiologist and physician, John Scott Haldane, suggested substituting canaries as a more sensitive but also revivable species (Burton 2014). The US Coal Mining Institute reached the same recommendation in 1914 (Pollock 2016). Through their own "citizen science," miners, however, may have already been using them in advance of Haldane's "scientific" discovery (Burton 2014). Mining companies then began purchasing the less operatic female birds as "pit" canaries for their workers ("colliers"). This was one of the first standardized occupational health protections, reportedly saving 800 lives a year in Britain (Burton 2014).

To my own surprise, the death of mining canaries proved more urban legend than actual proletarian history (see Figure 2). Miners cared dutifully, even lovingly, for their occupational pets, housing them in sophisticated resealable cages with oxygen bottles to resuscitate them after signs of distress (Pollard 2018; Pollock 2016). Due to their unique four chamber lungs, canaries inhale four times the amount of air as humans per unit of body mass. Fainting female canaries provided miners with a 20-minute warning to move to safety. Not until 1987 did British mining companies replace the last birds with digital air detectors known as "electronic noses" (Eschner 2016). Today, canaries are of interest in medical research for neurogenesis and neural plasticity.

Other environmentally ill folks have embraced the symbolism of being "miner's canaries," including Canary Kids (autism spectrum disorders), "Canary Narratives" (UCLA's oral history project about gender, chronic illness, and exposure); signals for Teflon toxicosis and other indoor air problems (EWG 2003); a third-party political movement for "Awareness; Precaution; Safety; Choice; Freedom; Justice; Scientific Integrity; Compassion"; and even a dating site (Canary Singles) for the chemically injured. Canaries have been an artistic inspiration for Thilde 
Figure 2. Canary resuscitator circa 1920-1930 (Source: Science Museum Group).

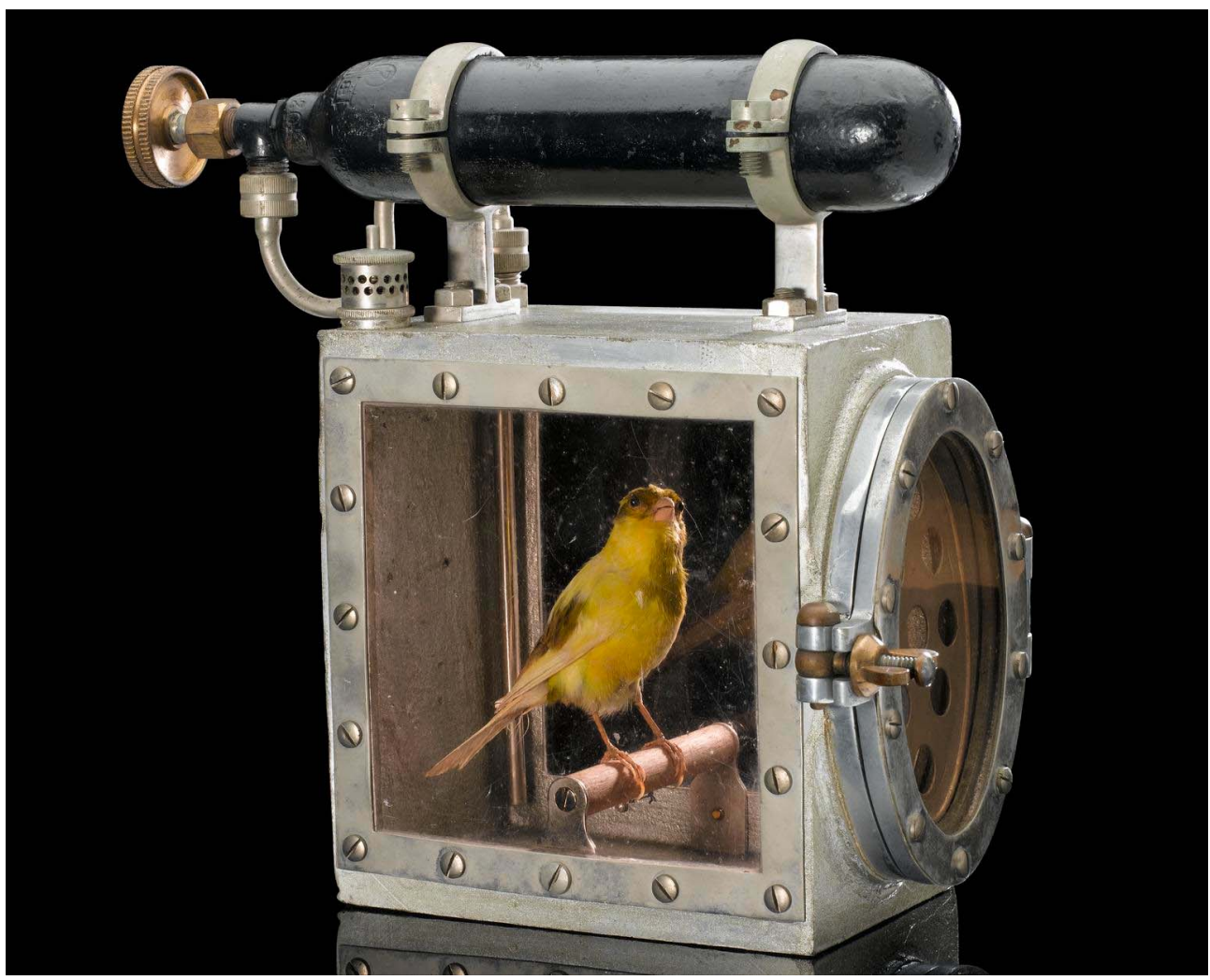

Jensen's captivating photo art book of MCS pathos (Rosenberg 2013). They starred in Amy Adams's encounters with aliens in the 2016 film "Arrival." A green Dutch chemical corporation that began as a coal mining company has even launched a nontoxic "Canary Life" home furnishing line.

Because I was so deeply brain-fogged from a botched university renovation in the mid-2010s (Grandia 2019), I cannot recollect how or where I first encountered the canary metaphor, but I do remember the profound emotional vindication that my chemical "sensitivities" might warn others of danger and allow them to live longer, healthier lives. I, therefore, began to construct a new line of research around toxics and to express my vulnerabilities more publicly. As Steve Kroll-Smith and H. Hugh Floyd (1997) describe, "bodies in protest" that smell at a magnitude of parts per billion more acutely than the general population must learn toxicology basics to convince others to modify their behavior (e.g., abstain from synthetically fragranced personal care products).

What I did not anticipate was the stunning number of students, staff, friends, colleagues, Guatemalan comrades from my previous fieldwork, and even strangers who responded to my vulnerable divulgences by opening up themselves about having also suffered in silence with their own scent-sitivities. One young man stood out. Out of respect for me, he had stopped wearing cologne on lecture days and noticed he could concentrate and think more clearly on those days. He ditched all his synthetic fragrances and went off his ADHD medicines; lo and behold, he did not have a learning disability_-just a bad case of Body Axe. Inspired by philosophy professor Antanas Mockus's success as two-term mayor of Bogotá in inducing remarkable cultural behavioral changes (gun control, tax compliance, and respect for traffic rules) and rebuilding respect 
Figure 3. "Professor Canary" (Source: Liza Grandia).

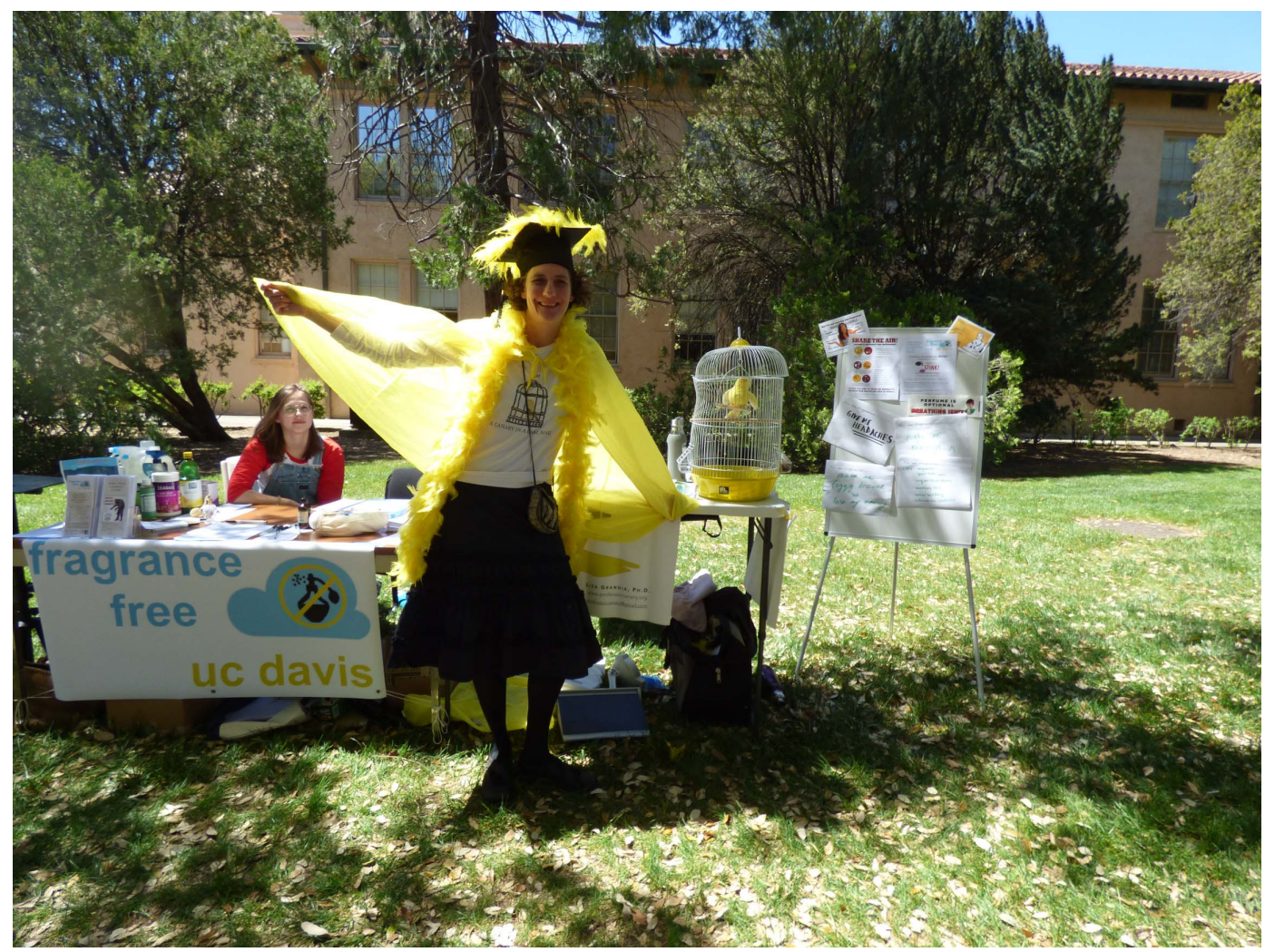

for regulatory government functions through his cape-costumed escapades as "Civic Man" ( $E l$ Hombre Cívico), I began to make campus appearances as "Professor Canary" in a yellow kaftan, boa, and befeathered mortarboard for my "Fragrance Free UCD" campaign.

When I took a series of toxicology courses through a Mellon fellowship, I worried that the professors would depreciate my low-dose vulnerabilities. Remarkably, however, many of them confessed that they shared my aversion to fragrances and offered alliances and expertise. University building managers who had previously ignored my suggestions for improved indoor air quality suddenly agreed to make fundamental procurement changes in flooring and cleaning products when I appeared in meetings accompanied by a distinguished, white-bearded toxicologist.

Through my public "Professor Canary" character, I wanted to emphasize that millions remain in limbo between home exclusion and exhausting ventures into everyday society and employment. Unfortunately, much of the scholarship and popular representations of MCS (e.g., Todd Haynes' film Safe and the current controversial Netflix series Afflicted) have profiled the extremes-people banished to desert communities or trapped in foiled and ventilated bedrooms. To capture those living somewhere in between exile and health, Jasbir Puar's (2017) thesis on the "right to maim" brilliantly proposes "debility" as a keyword for rethinking the "speediness" of trauma, risk management premised on death, and the epistemic Whiteness of disability studies. Building on Achille Mbembe's (2003: 21) idea that colonized bodies were "kept alive but in $a$ state of injury," Thom Davies (2018) argues that millions of workers are suspended in a temporal zone of just "getting by" while being slowly incapacitated by a corporate system that treats them as expendable reserve armies of labor. 
While the number of us with sufficiently severe "multiple chemical sensitivity" to be medically diagnosed was once in the first to second percentile, the number recently soared to 7.4 percent in a cross-sectional survey of 4,435 adults across four industrialized countries (Steinemann 2018). Another remarkable finding from these mass surveys is the high prevalence of people irritated by synthetic fragrances (32 percent) (Steinemann 2019). Complaints like headaches, respiratory problems, and mucosal symptoms are most commonly cited, but the list includes more severe and systemic effects like tachycardia (irregular heartbeat), muscular-skeletal pain, neurological cognition, and gastrointestinal problems, with each in the 4-7 percent range. For 9 percent of the general population, adverse reactions have caused them to miss work or lose employment. For 10-17 percent, air fresheners have made public spaces (restrooms, businesses, institutions) inaccessible (Steinemann 2019). A full half of respondents, including a number of "risk" experts of my acquaintance, would prefer fragrance-free spaces.

\section{When the Experts Become Canaries}

A handful of observant doctors began noticing this phenomenon and/or found themselves falling ill from common, everyday exposures. Before Silent Spring hit bookstores, allergist Theron Randolph (1906-1995) had just published his observations on idiopathic environmental illnesses and food allergies in 1962. Although his then-controversial ideas have since been validated, he lost his medical school faculty appointment and devoted himself to a new ward (an ECU, environmental control unit) that he founded at a Chicago hospital (Meggs 2017) to help patients detox so as to better assess what could be triggering their "petrochemical problem," which was his original descriptor for MCS. Debates among allergists became so acrimonious that Randolph and others broke from the American Academy of Allergy, Asthma, and Immunology to form a new professional association called the Society for Clinical Ecology in 1965, later renamed the American Academy of Environmental Medicine in 1985 (Randolph and Moss 1980) to defend their practices against industry-coordinated attacks (McCampbell 2001; Meggs 2017).

Among those treated by Randolph was the late William Rhea, a heart surgeon, who became so allergic to everyday objects that he became homeless. Tracing the sources of his own illness to lab chemicals and anesthesia in the operating room, Rhea began to associate home products with blood-clotting problems (thrombophlebitis) in his patients (an inflammatory condition also observed in those with severe or long COVID-19). Rhea then founded the Dallas Environmental Health Clinic in 1974, where among the patients that flocked to him he successfully treated a number of other incapacitated medical colleagues including Gerald Ross (poisoned by dry-cleaning fluid), Lisa Nagy (mercury poisoning), and Ann McCampbell (pesticides and mold in the home).

As the ranks of environmentally ill or environmentally aware doctors grew, by 1991 a workshop of the National Academy of Sciences published the first umbrella definition of "environmental illness" (Miller 1994). While I use MCS as the most widely recognized term, other proposed names include "the twentieth century disease" (Kroll-Smith and Floyd 1997); "allergy to modernity" (Radetsky 1997); "tight-building syndrome" (Grandia 2020), as well as ecological illness, odor induced asthma, chemical AIDS, cerebral allergy, chemically induced immune dysregulation, total allergy syndrome, toxic encephalopathy, or simply chemical hypersensitivity (Miller 1994). In collaboration with a chemist (Ashford and Miller 1991), allergist Claudia Miller proposed a qualitatively different theory that shifted the focus from the "sensitivity" of the afflicted to their environmental histories of exposure. For some, she argued, the "sensitizing 
event" was a memorable chemical accident—for example, an aerial pesticide spraying-but for others, it could be a chronic, low-level exposure such as working in a "sick building" (Miller 1994). Through what was later described as the "spreading effect," the chemically sensitized begin to react to chemically unrelated substances beyond the toxicants involved in their original triggering event (Miller 1994). Rejecting genetic predetermination, anyone could be susceptible to toxicant-induced loss of tolerance (TILT) (Miller 1997).

The inspiration for Miller's TILT trigger theory was the ironic experience of the EPA's own "sick building" problems in the late 1980s. Young scientists and medical doctors who would go on to become leading figures in indoor air quality (Lance Wallace) and environmental illness (Claudia Miller) were part of the team and/or peer reviewers that confirmed the scientists' selfcollected data that a semivolatile chemical from glues in new carpet was the primary culprit. Their 30-page survey of the sickened staff (more than 500 people, amounting to a fifth of the EPA's workforce) contains one of the most comprehensive symptomatic surveys on MCS (EPA 1991). While the EPA incident has been interpreted as a gendered and racialized crisis (and, to be sure, female African American clerical staff were uniquely vulnerable because the nature of secretarial work prevented relocations to alternative spaces) (Murphy 2006), the acutely ill also included a remarkable number of powerful White men. Among the toxicologists, chemists, and others represented by the professional unions was attorney Steve Shapiro, who testified to Congress about how he and other "people in their prime, in their twenties, ex-joggers, an ex-marathon runner, a karate black belt" (Lawson 1993: 168) were struck down by chemical sensitivity.

Until the EPA incident, many of the first-generation patients who had the time and resources in the 1980s and 1990s to seek formal medical diagnoses were homemakers (Miller 1994) more easily medically gaslighted as psychosomatically ill. While doctors in medical dramas work doggedly to crack diagnostics for rare and mysterious ailments, in real life one of the most common discussion topics on MCS social media groups is physician disbelief about their enigmatic symptoms. To this day, the US Department of Labor depicts MCS as "a highly controversial issue" with "insufficient evidence" of causality. The website states: "In theory, MCS is an adverse physical reaction to low levels of many common chemicals. Chemical sensitivity is generally accepted as a reaction to chemicals but debate continues as to whether MCS is classifiable as an illness" (OSHA 2020) and still cites a discredited editorial by retired colonel and medical doctor Roy Dehart (1998), who described MCS as a modern "hysterical epidemic" akin to nineteenth-century neurasthenia.

More intersectional and cross-class analyses are clearly needed to counterbalance the perception that MCS is an idle "White ladies" disease (Chen 2012). To draw attention to other "bodies in protest," Kroll-Smith and Floyd (1997) interviewed a remarkable cross-section of professionals with MCS including an industrial painter, dentist, former chemical engineer, chemist, product engineer, disabled building contractor, Defense Department analyst, college professor, attorney, product designer, librarian, marine transport dispatcher, and retired army colonel. Particularly striking was an ad executive's systematic tracking of how and why he reacts differently to newsprint, polyester, magic markers, electricity, or pool water. His somatic self-science could provide a curious toxicologist a lifetime's worth of research into toxicological pathways in bodies! Put together, their stories show that "chemical exposures do not obey systems of privilege" (Murphy 2004).

Another important cross-class canary study (volume and a film) was Alison Johnson's (2008; Johnson et al. 2006) work on "amputated lives" that compares the above EPA case to the cases of Exxon Valdez workers, Gulf Coast residents evacuated to those aforementioned FEMA trailers, and first responders at the World Trade Center after September 11, 2001. Especially notable are the estimated third of some 200,000 veterans from the 1990-1991 Persian Gulf War with idio- 
pathic, multisystem illnesses that are comparable to MCS (Miller and Phihoda 1999; Morgan and Fortun 2020): fatigue, depression, irritability, memory problems, muscle aches, shortness of breath, and chronic diarrhea. Perhaps explaining the "brain fog" that both Gulf War veterans and people suffering from MCS experience, they show similar patterns of brain injury (lessened blood flow) on SPECT scans (Heuser 1998; Johnson et al. 2006). While the Department of Veterans Affairs now provides some funding for Gulf War Illness research, support for other "canary-driven" science remains paltry, and publications related to MCS are stagnant despite its rising prevalence (Steinemann 2019; see Figure 4).

Figure 4. MCS Publications by Year (Source: Liza Grandia).

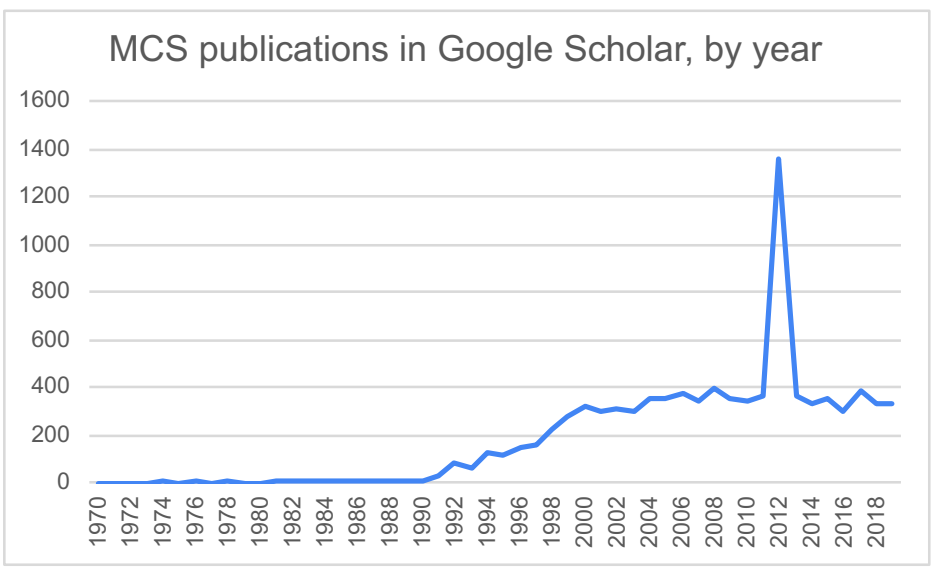

\section{New Directions in Environmental Health Research}

While diagnostics or treatment for MCS remain elusive, the testimonies and oral histories of "canaries in the mineshaft" have slowly begun to raise awareness of chemical harm in everyday life. As Alex Nading (2020: 210) emphasizes, polluted communities may perceive toxic harms in intuitive and sensorial ways that are missed by detached scientists. Historically, regulators only tracked single synthetic chemicals in the air, water, and consumer products, but not how pollution travels into living bodies, nor how "chemical cocktails" might interact with one another and create additional accidental by-products and metabolites within the blood. Frustrated with this bias, Ken Cook, executive director of the nonprofit Environmental Working Group, had an epiphany in 1999 that, if average people knew what was inside them, they might begin to look differently at pollution standards (Smith and Lourie 2009). In what became known as "body burden" research, his organization developed low-cost biomonitoring protocols to screen everyday citizens for portfolios of over 200 common synthetic chemicals. The CDC (2009) replicated this research in 1999 and found the almost universal presence of worrisome substances like BPA, polybrominated diphenyl ethers (flame retardants), perfluorinated chemicals from nonstick cookware, and volatile organic compounds like MTBE (methyl tert-butyl ether). In 2005, UK scientists reported the presence of numerous toxic chemicals in the umbilical cord blood of European babies (CDC 2009). The scandal of babies being born "pre-polluted" led the European Parliament to overhaul its risk assessment and registration processes and to require that industry begin to submit retroactive safety data on the estimated 85,000 untested chemicals in market circulation. However, current biomarker tests mostly capture synchronic exposure (what is circulating now in someone's blood). For understanding the depth, frequency, and latency of diachronic (past) exposures, epidemiological analysis remains essential. Adding intricacy to complexity, what apparently matters is not always how much of a substance to which an individual is exposed, but how sensitive, sensitized, or vulnerable that particular individual may be-whether through genes, diet, or contextual stress. 
Essentially employing participant observation methods, Nena Baker (2008), Smith and Lourie (2009), Sandra Steingraber (2001, 2011), Nick Shapiro (2007), and other long-form journalists have translated this science with lively, even humorous, reflexivity. Rick Smith and Bruce Lourie (2014) collaborated as sentinel guinea pigs to test their own blood to assess the efficacy of trendy "detox" methods. Among them were solutions and supplements (activated charcoal as a binder) that the "canary" community discovered in the 1970s and 1980s via word-of-mouth networks like the Chemical Injury Information Network long before they became popularized by the "wellness industry" and Hollywood actresses. Disabled canaries forced to rid their homes of all artifacts of "petrotopia" (Altman 2015) might help crack epidemiological puzzles with their unique somatic powers to correlate occasional or accidental exposures to adverse symptoms as well as ideas of how to recover from inflammatory conditions.

\section{Vulnerability in a Time of COVID}

Fast forward. Before public health authorities acknowledged that COVID-19 was not just a pneumonic virus but a multisystem disease that computer models now suggest may be connected to vascular and nerve damage, canaries saw reflections of their own hyperinflammatory symptoms. Whether brain fog, menstrual irregularities, leaky gut, heart arrhythmias, chronic fatigue, dysautonomia, impaired vagus nerve tone, mast cell activation, distorted smell, idiopathic rashes, memory loss, or headaches, this was a vocabulary of suffering in which the "millions missing" (those housebound by fatigue and allergies to modern life) were already well-versed. Being a long-hauler is, as an MCS canary described, like "having a body infested with dandelions ... [and never knowing] where or when the next group of weeds will sprout" (Kroll-Smith and Floyd 1997: 86).

Leading these critical connections is the Body Politic-a queer, feminist wellness collective (established in 2018) whose founders and creative directors, Fiona Lowenstein and Sabrina Bleich, happened to be among the first wave to fall ill with COVID-19 in early March 2020. As seasoned community organizers, they had the wherewithal to organize a Slack group (with 3,333 subscribers as of March 2021) to share experiences of illness, cycling symptoms, and unfolding research. An unusual number of academics (myself included), epidemiologists, and medical professionals were among the pandemic's first victims, and started proactive conversations about \#circulatory, \#respiratory, \#neurological, \#dysautonomia, \#vaccines, \#gastrointestinal, \#alternative-healing, and two dozen more topics. Every improvement I have made came from a patient tip and the raw, vulnerable testimony of medical doctors and nurses who provided affirmative company in our collective misery. With unprecedented speed, the CDC bowed to pressure to revise its diagnostics to include downright bizarre symptoms like chilblains or "COVID toes."

As the weeks passed, hundreds and then thousands reported in surveys and discussions that they had not gotten well after the two-week period espoused by the World Health Organization (WHO) guidelines. How and why some people suffered relapses and/or developed chronic fatigue and other stubborn postviral symptoms remains a mystery, but an estimated third of people who have contracted the virus continue to experience symptoms ("sequelae") after six weeks. Recent news suggests that even asymptomatic infection may morph into long-haul symptoms (Belluck 2021). Through their patient-led research and arduously crafted editorials under exhausting conditions (Lowenstein and Davis 2021) and amplified by sympathetic journalists (Yong 2020), the Body Politic shifted the COVID narrative from dichotomous well/sick to the question of long-term debility. 
Stricken journalists like Chris Cuomo now regularly invite COVID “long-haulers” to dialog live on television with medical doctors who might otherwise have dismissed their symptoms as psychogenic. The Body Politic presciently formed an ally Facebook group so that healthcare providers, wellness practitioners, lawyers, and researchers could survey and dialog with long-haulers in real time. As doctor William Li noted to the press: "This is a situation where doctors need to listen to patients who are bringing their symptoms to teach us, as a medical community, what's actually happening. It's the exact opposite of what normally happens, where doctors are telling the patients" (Sy 2021). Just as graduate students may be more familiar with contemporary scholarship than their overworked advisors, bed-bound patients may often be more versed in PubMed research or new clinicals than harried clinicians about the potential off-label prescription of ivermectin to treat COVID-19 (Chowdhury 2020).

Otherwise, doctors see and treat patients individually; at least in the United States, we have no national epidemiological tracking programs (with the exception of lead poisoning) to which patterns could be reported. Despite the medical aphorism "Listen to the patient-he/she/they are telling you the diagnosis" (Miller 1994: 265), in an age of genetics, the medical establishment remains concertedly ignorant of, if not hostile to, environmental causality. Even in known toxic areas, clinicians may not inquire about a patient's environmental history. In Woburn, Massachusetts-the town made famous by the book-turned-Hollywood film A Civil Action and that suffered a cluster of pediatric hematological cancers that were traced to emissions from a nearby tannery-an aftermath study found that local physicians were no more likely to ask about a patient's environmental exposure than doctors elsewhere (Brown 2001).

As an afflicted ethnographer unwillingly drawn into virtual participant observation about COVID-19 (Adams and Nading 2020), I have tracked social media posts with an ethnographic eye for narrative patterns. On glass-half-empty days, I notice that a striking number of people-mostly women - still report being dismissed and medically gaslighted with psychosomatic diagnostics (depression, irritable bowel syndrome (IBS), and anxiety). This reflects a true crisis of curiosity among family practitioners and disregard for context (a global pandemic of a rapidly mutating and still poorly understood virus!). On glass-half-full days, however, long-haulers are heartened when the many medical workers in our ranks express humility and calls-to-action (Gorna et al. 2020; Gulliver Casperson 2020) or use their "professional power" (Callard and Perego 2021: 7) to amplify patient contributions. While the "amazing grace" stories of medical doctors and "wounded healers" (Ladds et al. 2021) are too numerous to cite here, I quote one due to its JAMA publication prominence:

I have been reminded of the need to listen to the patient first, even in the absence of conclusive testing. The next time I care for someone with vague abdominal pain, or fatigue, or paresthesia, or any of the myriad conditions that are uncomfortable on the inside but look fine on the outside, I will remember that these symptoms are real and impactful for patients. (Siegelman 2020: 2031)

These doctor canary testimonies show that occasionally the "temporal cohesiveness" of a professional group sickened from an exposure event (like the carpeted EPA) may help legitimate the illness to other clinicians.

Seizing the moment, scholar Jennifer Brea has been unusually proactive in building communications linkages between those with chronic fatigue (technically known as ME or myalgic encephalomyelitis) and the long-haulers. While somehow filming a hauntingly vulnerable autobiographical documentary, Unrest (2017), about her own descent into crippling fatigue after a viral illness, she also co-founded \#MEAction to raise awareness, compassion, and money for research on the "millions missing" from life (Gibson 2009). The MCS community unfortunately 
has been less proactive than Brea and the ME/CFS (chronic fatigue syndrome) community in seeking allyship for their condition among the long-haulers. From my social media chat threads, I have nevertheless noted that a remarkable number of COVID-19 long-haulers are reporting sudden and new aversions to synthetic smells; others describe phantom smells like burned motor oil. Given the unprecedented application of fragranced disinfectants everywhere, nested among the long-haul sufferers may be newly TILTed canaries who have been sensitized to everyday petrochemicals.

In contrast to MCS, which still lacks legitimating diagnostics six decades after Randolph (1962) first described it, the CDC in January 2021 announced six new ICD-10-CM codes to describe COVID-19 symptoms including M35.81 for the multisystem inflammatory syndrome seen in children (CDC 2020). Then in February 2021, Anthony Fauci, director of the National Institute of Allergy and Infectious Diseases (NIAID), announced an official term, PASC ("PostAcute Sequelae of SARS-CoV-2 infection"), to validate the experiences of those suffering from long COVID. Congress then allotted an astounding $\$ 1.15$ billion to the NIH to study the condition (Edwards 2021).

In the continued absence of the rigorous regulatory structures needed to track and monitor chronic diseases and their linkages with environmental hazards, my humble provocation here has been to suggest a few ways in which environmental health research may benefit from curiosity about canaries, whose outpost sensitivities should never, ever be "cleaned" from datasets. Epigenetic studies suggest that the full scope of humanity's toxic exposures have yet to unfold. The universality and multiplicity of exposures may make it increasingly difficult for humanity to untangle the residues, but early trust for distress signals of/by/about canaries (what I call here "canary science") could move environmental epidemiological research in new directions. Should industrialized societies acknowledge the chemical cesspool they have created and then be willing to listen to some solid social "detox" advice, environmentally disabled and chemically injured folk have acquired some hard-earned knowledge for survival. In addition, Native and Indigenous peoples have accumulated five centuries of hard-learned wisdom about resilience from historic trauma, cultural survivance, and the precarious art of living on despoiled territories (Gross 2013).

Canaries may not have the physical energy to do this research themselves. ${ }^{4}$ If the reader will forgive the multiple animal metaphors, we are canaries, not sacrificial lambs. Canaries demonstrate their vulnerability, but in turn miners cared for their canaries and rescued them so that they might work another day. Beyond offering intriguing epidemiological clues to what may be happening writ large in industrial societies, canaries are discovering new methods for healing outside of Western science and allopathic health systems (Vickery and Hunter 2016). Above all, canaries demonstrate an agentive capacity to teach us all about mutual susceptibilities to toxics. Expressing vulnerability takes courage. Attunement is a skill, not a debility.

LIZA GRANDIA is an Associate Professor in the Department of Native American Studies at the University of California, Davis. As a cultural anthropologist, she has collaborated with environmental, agrarian, and social justice projects over nearly three decades in northern Guatemala and southern Belize. She received a 2017-2019 Mellon "New Directions" fellowship for retraining in toxicology and environmental epidemiology and is now pursuing research into pesticides, GMOs, and cultural perceptions of toxics in everyday life. A 13-year survivor of lymphoma, which left her with multiple chemical sensitivities, she moonlights as "Professor Canary" and has won several awards for this grassroots activism. Email: lgrandia@ucdavis.edu 


\section{NOTES}

1. Thanks to two anonymous reviewers and editor Alex Nading for incisive comments and copious citational suggestions.

2. Given that COVID-19 infections may lead to infertility in men and striking hormonal imbalances in women, perhaps public health leaders might speak more often about gonad vulnerability to the virus.

3. Personal communication, Gwen Ottinger, 30 April 2018.

4. To that end, I am most grateful to my patient volume and journal editors for numerous extensions through my convalescence. Epidemiological and toxicological training from a Mellon Foundation "New Directions" Fellowship helped me parse PubMed literature for medicines and herbs to survive COVID-19 in the first wave of infections in April 2020 to live to write this article. My little canary, Adelaide, gave me the motivation to do so. Last but not least, I am grateful to my enlightened doctors for their receptivity to insights from canary science.

\section{REFERENCES}

Aamjiwnaang First Nation. "History." n.d. https://www.aamjiwnaang.ca/history/ (accessed 9 March 2021).

Adams, Vincanne, and Alex M. Nading. 2020. "Medical Anthropology in the Time of COVID-19." Medical Anthropology Quarterly 34 (4): 461-466. doi:10.1111/maq.12624.

Allison, Anne. 2014. "Precarity: Editorial Commentary." Cultural Anthropology 29 (1). https://journal .culanth.org/index.php/ca/catalog/category/precarity.

Altman, Rebecca Gasior. 2015. "Petro-Topia." Aeon. https://aeon.co/essays/plastics-run-in-my-familybut-their-inheritance-is-in-us-all (accessed 5 October 2020)

Andersen, Martin Edwin. 2010. Peoples of the Earth: Ethnonationalism, Democracy and the Indigenous Challenge. Lanham, MD: Lexington Books.

Anderson, Benedict. 1983. Imagined Communities: Reflections on the Origin and Spread of Nationalism. New York: Verso.

Ashford, Nicholas, and Claudia Miller. 1991. Chemical Exposures: Low Levels and High Stakes. New York: Van Nostrand Reinhold.

Baker, Beth. 2016. "Frontiers of Citizen Science." BioScience 66: 921-927. doi:10.1093/biosci/biw120.

Baker, Lois. 1997. "Growing Cancer Threat among Native Americans Receiving Scant Attention." University of Buffalo News, 30 January. http://www.buffalo.edu/news/releases/1997/01/3015.html.

Baker, Nena. 2008. The Body Toxic: How the Hazardous Chemistry of Everyday Things Threatens Our Health and Well-Being. New York: North Point Press.

Beamish, Thomas. 2001. "Environmental Hazard and Institutional Betrayal: Lay-Public Perceptions of Risk in the San Luis Obispo County Oil Spill." Organization and Environment 14: 5-33. https:// doi.org/10.1177/1086026601141001

Belluck, Pam. 2021. "Many 'Long Covid' Patients Had No Symptoms from Their Initial Infection." New York Times, 8 March. https://www.nytimes.com/2021/03/08/health/long-covid-asymptomatic .html? referringSource=articleShare.

Bienkowski, Brian. 2002. "Contaminated Culture: Native People Struggle with Tainted Resources, Lost Identity." Environmental Health News, 25 October. https://www.ehn.org/us-urged-to-cut-50-ofemissions-by-2030-to-spur-other-countries-to-action-us-news-the-guardian-2650997040.html.

Bilott, Robert. 2019. Exposure: Poisoned Water, Corporate Greed, and One Lawyer's Twenty-Year Battle against DuPont. New York: Atria Books.

Biolsi, Thomas. 2002. "Review Essay on Tribes Treaties, and Constitutional Tribulations by Vine Deloria Jr. and David E. Wilikins." Wicazo Sa Review 17 (1): 242-246. https://www.jstor.org/stable/1409568.

Bonney, Rick, Jennifer L. Shirk, Tina B. Phillips, Andrea Wiggins, Heidi L. Ballard, Abraham J. MillerRushing, and Julia K. Parrish. 2014. "Next Steps for Citizen Science." Science 343: 1436-1437. doi:10.1126/science.1251554. 
Boudia, Soraya, Angela N. H. Creager, Scott Frickel, Emmanuel Henry, Nathalie Jas, Carsten Reinhardt, and Jody A. Roberts. 2018. "Residues: Rethinking Chemical Environments." Engaging Science, Technology, and Society 4: 165-178. doi:10.17351/ests2018.245.

Brea, Jennifer. 2017. Unrest. Independent Lens.

Brown, Phil. 1992. "Popular Epidemiology and Toxic Waste Contamination: Lay and Professional Ways of Knowing." Journal of Health and Social Behavior 33: 267-281. doi:10.2307/2137356.

Brown, Phil. 2001. "Environmental Health and Safety: Social Aspects." In International Encyclopedia of the Social and Behavioral Sciences, ed. Neil J. Smelser and Paul B. Baltes, 4617-4621. New York: Elsevier.

Buell, Lawrence. 1998. “Toxic Discourse.” Critical Inquiry 24 (3): 639-665. doi:10.1086/448889.

Burton, Catherine. 2014. "Risking Life and Wing: Victorian and Edwardian Conceptions of Coal-Mine Canaries." Victorian Review 40: 143-159. doi:10.1353/vcr.2014.0029.

Butler, Judith. 2009. "Performativity, Precarity and Sexual Politics." AIBR, Revista de Antropología Iberoamericana 4 (3): i-xiii. doi:10.11156/aibr.040305.

Callard, Felicity, and Elisa Perego. 2021. "How and Why Patients Made Long Covid." Social Science e Medicine 268 (113426): 1-13. doi:10.1016/j.socscimed.2020.113426.

Carson, Rachel. 1962. Silent Spring. Boston: Houghton Mifflin Company.

CDC (Centers for Disease Control and Prevention). 2009. Fourth National Report on Human Exposure to Environmental Chemicals: Executive Summary. Atlanta: Department of Health and Human Services, Centers for Disease Control and Prevention, and National Center for Environmental Health.

CDC (Centers for Disease Control and Prevention). 2020. "New ICD-10-CM Code for the 2019 Novel Coronavirus (COVID-19)." CDC, 3 December. https://www.cdc.gov/nchs/data/icd/AnnouncementNew-ICD-code-for-coronavirus-19-508.pdf.

Changing Markets Foundation. 2018. Testing Carpet for Toxics: Chemicals Affecting Human Health and Hindering the Circular Economy. Amsterdam: Changing Markets Foundation, Ecology Center, and GAIA.

Checker, Melissa. 2007. “'But I Know It’s True’: Environmental Risk Assesment, Justice and Anthropology." Human Organization 66 (2): 112-124. doi:10.17730/humo.66.2.1582262175731728.

Chen, Mel Y. 2011. “Toxic Animacies, Inanimate Affections." GLQ: A Journal of Gay and Lesbian Studies 17 (2-3): 265-286. doi:10.1215/10642684-1163400.

Chen, Mel Y. 2012. "Masked States and the 'Screen' between Security and Disability." WSQ: Women's Studies Quarterly 40 (1-2): 76-96. doi:10.1353/wsq.2012.0004.

Chowdhury, Abu Taiub Mohammed Mohiuddin. 2020. "A Comparative Study on Ivermectin and Hydroxychloroquine on the COVID-19 Patients in Bangladesh." Upazila Health \& Family Planning Officer's (UHFPO) Office 2020. https://clinicaltrials.gov/ct2/show/NCT04434144 (accessed 12 August 2020).

Corburn, Jason. 2005. Street Science: Community Knowledge and Environmental Health Justice. Cambridge, MA: MIT Press.

Couch, Stephen R., and J. Stephen Kroll-Smith. 1985. "The Chronic Technical Disaster: Toward a Social Scientific Perspective.” Social Science Quarterly 66 (3): 564-575. https://www.jstor.org/stable/42861944.

Davies, Thom. 2018. “Toxic Space and Time: Slow Violence, Necropolitics, and Petrochemical Pollution." Annals of the American Association of Geographers 108 (6): 1537-1553. doi:10.1080/24694452.2018 .1470924 .

Dehart, Roy L. 1998. “Multiple Chemical Sensitivity.” American Family Physician 58 (3): 652-654. https://www.aafp.org/afp/1998/0901/p652.html.

Douglas, Mary. 1966. Purity and Danger: An Analysis of the Concepts of Pollution and Taboo. New York: Routledge.

Douglas, Mary, and Aaron Wildavsky. 1983. Risk and Culture: An Essay on the Selection of Technological and Environmental Dangers. Berkeley: University of California Press.

Edwards, Erika. 2021. Why Do Some COVID-19 Patients Have Symptoms Long after the Virus Goes Away? NIH Aims to Find Out. NBC News, 24 February. https://www.nbcnews.com/health/healthnews/why-do-some-covid-19-patients-have-symptoms-long-after-n 1258756. 
EPA (US Environmental Protection Agency). 1991. Indoor Air Quality and Work Environment Series, EPA Headquarters Buildings Research Triangle Park, NC: U.S. Environmental Protection Agency, Atmospheric Research and Exposure Assessment Laboratory Office of Research and Development.

EPA (US Environmental Protection Agency). 2013. "Bisphenol-A.” In America's Children and the Environment. Washington, DC: US Environmental Protection Agency.

Eschner, Kat. 2016. "The Story of the Real Canary in the Coal Mine." Smithsonian Magazine, 30 December. https://www.smithsonianmag.com/smart-news/story-real-canary-coal-mine-180961570/.

EWG (Environmental Working Group). 2003. "Canaries in the Kitchen.” EWG, 15 May. https://www .ewg.org/research/canaries-kitchen.

Ferguson, James. 1994. The Anti-Politics Machine: Development, Depoliticization and Bureaucratic Power in Lesotho. Minneapolis: University of Minnesota Press.

Feyerabend, Paul. 1978. Science in a Free Society. New York: Schocken Books.

Flynn, James, Paul Slovic, and C. K. Mertz. 1994. "Gender, Race, and Perception of Environmental Health Risks.” Risk Analysis 14 (6): 1101-1108. doi:10.1016/j.jbusres.2020.05.031.

Gibson, Pamela Reed. 2009. "Of the World But Not in It: Barriers to Community Access and Education for Persons with Environmental Sensitivities." Health Care for Women International 31 (1): 3-16. doi:10.1080/07399330903042823.

Gilio-Whitaker, Dina. 2019. As Long as Grass Grows: The Indigenous Fight for Environmental Justice from Colonization to Standing Rock. Boston: Beacon Press.

Gorna, Robin, Nathalie MacDermott, Clare Rayner, Margaret O’Hara, Sophie Evans, Lisa Agyen, ..., and Will Nutland. 2020. "Long COVID Guidelines Need to Reflect Lived Experience." The Lancet 397: 455-457. doi:10.1016/S0140-6736(20)32705-7.

Grandia, Liza. 2019. “Toxic Tropics: Purity and Danger in Petén, Guatemala.” Journal of Ecological Anthropology 21 (1): 1-6. doi:10.5038/2162-4593.21.1.1243.

Grandia, Liza. 2020. “Toxic Gaslighting: On the Ins and Outs of Pollution.” Engaging Science, Technology, and Society 6: 486-513. doi:10.17351/ests2020.431.

Gross, Lawrence W. 2013. Anishinaabe Ways of Knowing and Being. New York: Routledge.

Guha, Ramachandra, and Joan Martinez-Alier. 1997. Varieties of Environmentalism: Essays North and South. London: Earthscan Publications.

Guinier, Lani, and Gerald Torres. 2002. The Miner's Canary: Enlisting Race, Resisting Power, Transforming Democracy. Cambridge, Ma.: Harvard University Press.

Gulliver Casperson, Shannon. 2020. "When the Doctor Is a Covid 'Long Hauler." New York Times, 21 October. https://www.nytimes.com/2020/10/21/well/live/when-the-doctor-is-a-covid-longhauler.html? referringSource=articleShare.

Gusterson, Hugh. 1996. Nuclear Rites: A Weapons Laboratory at the End of the Cold War. Berkeley: University of California Press.

Haklay, Muki. 2018. "Participatory Citizen Science." In Citizen Science: Innovation in Open Science, Society and Policy, ed. Susanne Hecker, Muki Haklay, Anne Bowser, Zen Makuch, Johannes Vogel, and Aletta Bonn, 52-62. London: UCL Press.

Han, Clara. 2018. "Precarity, Precariousness, and Vulnerability." Annual Review of Anthropology 47: 331-343. doi:10.1146/annurev-anthro-102116-041644.

Hardon, Anita. 2021. Chemical Youth: Navigating Uncertainty in Search of the Good Life. Cham, Switzerland: Palgrave Macmillan.

Heuser, Gunnar. 1998. "Neurospect in Neurotoxic Chemical Exposure Demonstration of Long-Term Functional Abnormalities." Toxicology and Industrial Health 14 (6): 814-827. doi:10.1177/074823 379801400604 .

Hoover, Elizabeth. 2017. The River Is In Us: Fighting Toxics in a Mohawk Community. Minneapolis: University of Minnesota Press.

Hoover, Elizabeth, Katsi Cook, Ron Plain, Kathy Sanchez, Vi Waghiyi, Pamela Miller, ..., and Renee Dufault. 2012. "Indigenous Peoples of North America: Environmental Exposures and Reproductive Justice." Environmental Health Perspectives 120 (12): 1645-1649. doi:10.1289/ehp.1205422. 
Johnson, Alison. 2008. Amputated Lives: Coping with Chemical Sensitivity. Brunswick, ME: Cumberland Press.

Johnson, Alison, Richard Startzman, and Brien White. 2006. Multiple Chemical Sensitivity: How Chemical Exposures May Be Affecting Your Health. Santa Fe: CineVision Media. USA.

Kasmir, Sharryn. 2018. "Precarity." In Cambridge Encyclopedia of Anthropology. doi:10.29164/18precarity.

Kellow, Aysley. 1999. International Toxic Risk Management: Ideals, Interests and Implementation. New York: Cambridge Univeristy Press.

Kroll-Smith, Steve, and H. Hugh Floyd. 1997. Bodies in Protest: Environmental Illness and the Struggle over Medical Knowledge. New York: NYU Press.

Ladds, Emma, Alex Rushforth, Sietse Wieringa, Sharon Taylor, Clare Rayner, Laiba Husain, and Trisha Greenhalgh. 2021. "Developing Services for Long COVID: Lessons from a Sudy of Wounded Healers." Clinical Medicine 21 (1): 59-65.

LaDuke, Winona. 1982. "Nature, Natives, and Technology." Science for the People 14 (5): 24-28. https:// archive.scienceforthepeople.org/vol-14/v14n5/nature-natives-and-technology/.

Landrigan, Philip J., and Mary M. Landrigan. 2018. Children and Environmental Toxins: What Everyone Needs to Know. New York: Oxford University Press.

Lawson, Lynn. 1993. Staying Well in a Toxic World: Understanding Environmental Illness, Multiple Chemical Sensitivities, Chemical Injuries, Sick Building Syndrome. Chicago: Noble Press, Inc.

Levine, Hagai, Niels Jørgensen, Anderson Martino-Andrade, Jaime Mendiola, Dan Weksler-Derri, Irina Mindlis, ... and Rachel Pinotti. 2017. "Temporal Trends in Sperm Count: A Systematic Review and Meta-Regression Analysis." Human Reproduction Update 23 (6): 646-659. doi:10.1093/humupd/ dmx022.

Lora-Wainwright, Anna. 2010. “An Anthropology of 'Cancer Villages': Villagers' Perspectives and the Politics of Responsibility." Journal of Contemporary China 19 (63): 79-99. doi:10.1080/10670560 903335785.

Lowenstein, Fiona, and Hannay Davis. 2021. "Long Covid Is Not Rare: It’s a Health Crisis.” New York Times, 17 March. https://www.nytimes.com/2021/03/17/opinion/long-covid.html?referring Source=articleShare\&fbclid=IwAR3mdNv4L4rCmPnQ_nbu9a4mWNutcjxLPECMjOWqoozV0m qui-4vhU9C08.

Mbembe, Achille. 2003. "Necropolitics." Public Culture 15 (1): 11-40. https://muse.jhu.edu/article/39984.

McCampbell, Ann. 2001. "Multiple Chemical Sensitivities under Siege." Townsend Letter for Doctors and Patients (210). https://annmccampbellmd.com/publicationswritings/publication-1/.

Meggs, William. 2017. "History of the Rise and Fall of Environmental Medicine in the United States." Ecopsychology 9 (2): 72-79. doi:10.1089/eco.2016.0044.

Miller, Claudia S. 1994. "White Paper: Chemical Sensitivity, History and Phenomenology." Toxicology and Industrial Health 10 (4-5): 253-276. doi:10.1177/074823379401000501.

Miller, Claudia S. 1997. “Toxicant-Induced Lack of Tolerance: A Emerging Theory of Disease?” Environmental Health Perspectives 105 (2): 445-453. doi:10.1289/ehp.97105s2445.

Miller, Claudia S., and Thomas J. Phihoda. 1999. "A Controlled Comparison of Symptoms and Chemical Intolerances Reported by Gulf War Veterans, Implant Recipients and Persons with Multiple Chemical Sensitivity." Toxicology and Industrial Health 15 (3-4): 386-397. doi:10.1177/074823 379901500312.

Miller, Pamela K, Viola Waghiyi, Gretchen Welfinger-Smith, Samuel Carter Byrne, Jane Kava, Jesse Gologergen, ..., and Lorraine Eckstein. 2013. "Community-Based Participatory Research Projects and Policy Engagement to Protect Environmental Health on St. Lawrence Island, Alaska." International Journal of Circumpolar Health 72 (1): 21656. doi:10.3402/ijch.v72i0.21656.

Morgan, Alli, and Kim Fortun. 2020. “Toxic Soldiers, Flickering Knowledges, and Enlisted Care." Catalyst: Feminism, Theory, Technoscience 6 (1). doi:10.28968/cftt.v6i1.32808.

Murphy, Michelle. 2004. "Uncertain Exposures and the Privilege of Imperception: Activist Scientists and Race at the U.S. Environmental Protection Agency." Osiris, 2nd series 19: 266-82. https://www.jstor .org/stable/3655244 
Murphy, Michelle. 2006. Sick Building Syndrome and the Problem of Uncertainty. Durham, NC: Duke University Press.

Murphy, Michelle. 2008. “Chemical Regimes of Living.” Environmental History 13 (4): 695-703. https:// www.jstor.org/stable/25473297.

Murphy, Michelle. 2020. "Some Keywords toward Decolonial Methods: Studying Settler Colonial Histories and Environmental Violence from Tkaronto." History and Theory 59 (3): 376-384. doi:10.1111/ hith.12165.

Nadasdy, Paul. 1999. “The Politics of TEK: Power and the 'Integration' of Knowledge." Arctic Anthropology 36 (1-2): 1-18. https://www.jstor.org/stable/40316502.

Nader, Laura. 1995. "Energy Needs for Sustainable Human Development from an Anthropological Perspective." In Energy as an Instrument for Socio-Economic Development, ed. José Goldemberg and Thomas B Johansson, 42-48. New York: UNDP.

Nader, Laura. 1996. Naked Science: Anthropological Inquiry into Boundaries, Power, and Knowledge. New York: Routledge.

Nading, Alex M. 2020. "Living in a Toxic World." Annual Review of Anthropology 49: 209-224. doi:10 .1146/annurev-anthro-010220-074557.

Oliver-Smith, Anthony. 1996. "Anthropological Research on Hazards and Disasters." Annual Review of Anthropology 25: 303-28.

OSHA (Occupational Safety and Health Administration). 2020. "Multiple Chemical Sensitivities." 2020. https://www.osha.gov/multiple-chemical-sensitivities (accessed 15 September 2020).

Ottinger, Gwen. 2010. "Buckets of Resistance: Standards and the Effectiveness of Citizen Science." Science, Technology \& Human Values 35 (2): 244-270. doi:10.1177/0162243909337121.

Ottinger, Gwen, and Benjamin R. Cohen. 2011. Technoscience and Environmental Justice: Expert Cultures in a Grassroots Movement. Boston: MIT Press.

Pezzullo, Phaedra C. 2014. "Contaminated Children: Debating the Banality, Precarity, and Futurity of Chemical Safety." Resilience: A Journal of the Environmental Humanities 1 (2): 1-21. doi:10.5250/ resilience.1.2.004.

Polanyi, Karl. 1944. The Great Transformation. New York: Rinehart and Company, Inc.

Pollard, Lewis. 2018. "Exploring Our Collection: The Canary Resuscitator." Science+Industry Museum, 27 March. https://blog.scienceandindustrymuseum.org.uk/canary-resuscitator/.

Pollock, Christal. 2016. “The Canary in the Coal Mine." Journal of Avian Medicine and Surgery 30 (4): 386-391. doi:10.1647/1082-6742-30.4.386.

Puar, Jasbir K. 2017. The Right to Maim: Debility, Capacity, Disability. Durham, NC: Duke University Press.

Radetsky, Peter. 1997. Allergic to the Twentieth Century: The Explosion in Environmental Allergies-From Sick Buildings to Multiple Chemical Sensitivity. Boston: Little, Brown, and Company.

Randolph, Theron G. 1962. Human Ecology and Susceptibility to the Chemical Environment. Springfield, IL: CC Thomas.

Randolph, Theron G., and Ralph W. Moss. 1980. An Alternative Approach to Allergies: The New Field of Clinical Ecology Unravels the Environmental Causes of Mental and Physical Ills. New York: Harper \& Row Publishers.

Rawls, John. 1971. A Theory of Justice. New York: Belknap.

Rea, William. 1992-1997. Chemical Sensitivity. 4 Vols. Boca Raton, FL: Lewis Publishers.

Redd, Stephen C. 2002. "Asthma in the United States: Burden and Current Theories." Environmental Health Perspectives 110 (4): 557-560. doi:10.1289/ehp.02110s4557.

Rosenberg, David. 2013. “The Air Is Poison.” Slate, 1 February. https://slate.com/culture/2013/02/thildejensen-canaries-documents-the-isolating-and-frightening-lives-of-those-who-suffer-from-environ mental-illness-photos.html.

Shadaan, Reena, and Michelle Murphy. 2020. "Endocrine-Disrupting Chemicals (EDCs) as Industrial and Settler Colonial Structures: Towards a Decolonial Feminist Approach." Catalyst: Feminism, Theory, Technoscience 6 (1): 1-36. doi:10.28968/cftt.v6i1.32089. 
Shapiro, Nick. 2014. "Un-knowing Exposure: Toxic Emergency Housing, Strategic Inconclusivity and Governance in the US Gulf South." In Knowledge, Technology, and Law, ed. Emilie Cloatre and Martyn Pickersgill, 189-205. New York: Routledge.

Siegelman, Jeffrey N. 2020. "Reflections of a COVID-19 Long Hauler." JAMA 324 (20): 2031-2032. doi:10.1001/jama.2020.22130.

Singer, Merrill, and Scott Clair. 2003. "Syndemics and Public Health: Reconceptualizing Disease in Bio-Social Context.” Medical Anthropology Quarterly 17 (4): 423-441. doi:10.1525/maq.2003.17.4 .423 .

Smith, Rick, and Bruce Lourie. 2009. Slow Death by Rubber Duck: The Secret Danger of Everyday Things. Berkeley: Counterpoint.

Smith, Rick, and Bruce Lourie. 2014. Toxin Toxout: Getting Harmful Chemicals out of Our Bodies and Our World. New York: St. Martin's Press.

Standing, Guy. 2014. “The Precariat.” Contexts 13 (4): 10-12. doi:10.1177/1536504214558209.

Starr, Chauncey. 1969. "Social Benefit versus Technological Risk." Science 236 (4799): 280-285. doi:10 $.1126 /$ science.165.3899.1232.

Steinemann, Anne. 2018. "International Prevalence of Chemical Sensitivity, Co-Prevalences with Asthma and Autism, and Effects from Fragranced Consumer Products." Air Quality, Atmosphere \& Health 12: 519-527. doi:10.1007/s11869-019-00672-1.

Steinemann, Anne. 2019. “International Prevalence of Fragrance Sensitivity." Air Quality, Atmosphere \& Health 12: 891-897. doi:10.1007/s11869-019-00699-4.

Steingraber, Sandra. 1997. Living Downstream: An Ecologist Looks at Cancer and the Environment. Reading, MA: Addison-Wesley Publishing.

Steingraber, Sandra. 1998. "Living Downstream: An Interview with Sandra Steingraber." Multinational Monitor 19 (3): 20-24. https://multinationalmonitor.org/mm1998/98mar/interview.html.

Steingraber, Sandra. 2001. Having Faith: An Ecologist's Journey to Motherhood. Cambridge, MA: Perseus.

Steingraber, Sandra. 2011. Raising Elijah: Protecting Our Children in an Age of Environmental Crisis. Philadelphia: Da Capo Press.

Stevens, Matthias, Michalis Vitos, Julia Altenbuchner, Gillian Conquest, Jerome Lewis, and Muki Haklay. 2014. “Taking Participatory Citizen Science to Extremes." Pervasive Computing 13 (2): 20-29. doi:10.1109/MPRV.2014.37.

Stewart, Kathleen, and Susan Harding. 1999. "Bad Endings: American Apocalypsis.” Annual Review of Anthropology 28: 285-310. doi:10.1146/annurev.anthro.28.1.285.

Sy, Stephanie. 2021. "Medical Community Scrambles to Understand COVID-19 'Long Haulers.” PBS News Hour, 13 January. https://www.pbs.org/newshour/show/medical-community-scrambles-tounderstand-covid-19-long-haulers.

Toledano, Michael. 2013. “A Toxic Tour of Canada’s Chemical Valley.” Vice, 23 March. https://www.vice .com/en/article/vdy948/a-toxic-tour-of-canadas-chemical-valley.

Tsing, Anna Lowenhaupt. 2015. The Mushroom at the End of the World: On the Possibility of Life in Capitalist Ruins. Princeton, NJ: Princeton University Press.

Vickery, Jamie, and Lori M. Hunter. 2016. "Native Americans: Where in Environmental Justice Research?” Sociology and Natural Resources 29 (1): 36-52. doi:10.1080/08941920.2015.1045644.

Weaver, Jace. 2010. Notes from a Miner's Canary: Essays on the State of Native America. Albuquerque: University of New Mexico Press.

West, Sarah, Rachel Pateman, and Alison Dyke. 2016. Data Submission in Citizen Science Projects. Defra Project number PH0475: Stockholm: Stockholm Environment Institute and University of York. https://www.york.ac.uk/media/sei/documents/publications/projectreports/West-Pateman-DykeDEFRA-Data-Submission-in-Citizen-Science-Projects.pdf.

Weston, Kath. 2012. "Political Ecologies of the Precarious." Anthropological Quarterly? 85 (2): 429-455. doi:10.1353/anq.2012.0017.

WHO. 2021. "Cancer." Geneva: World Health Organization. https://www.who.int/news-room/factsheets/detail/cancer (accessed 2 May 2021). 
WHO (World Health Organization) and International Union against Cancer. 2005. Global Action Against Cancer. Geneva: WHO and International Union against Cancer. https://apps.who.int/iris/ handle/10665/43203.

Worsely, Peter. 1997. Knowledges: Culture, Counterculture, Subculture. New York: New Press.

Yong, Ed. 2020. "Long-Haulers and Redefining COVID-19." The Atlantic, 19 August. https://www .theatlantic.com/health/archive/2020/08/long-haulers-covid-19-recognition-support-groupssymptoms/615382/. 